\title{
SOIL STRUCTURE AND SOIL ORGANIC MATTER OF SELECTED SOIL TYPES IN DIFFERENT ECOSYSTEMS
}

\author{
ERIKA TOBIAŠOVÁ ${ }^{1 *}$ - VLADIMÍR ŠIMANSKÝ ${ }^{1}-$ BOŻENA DĘBSKA $^{2}$ \\ - MAGDALENA BANACH-SZOTT2 \\ ${ }^{1}$ Slovak University of Agriculture in Nitra \\ ${ }^{2}$ University of Technology and Life Sciences Bydgoszcz
}

TOBIAŠOVÁ, E. - ŠIMANSKÝ, V. - DĘBSKA, B. - BANACH-SZOTT, M.: Soil structure and soil organic matter of selected soil types in different ecosystems. Agriculture (Pol'nohospodárstvo), vol. 59, 2013, no. 1, pp. 1-8.

In this study, differences in soil structure in different ecosystems (forest, meadow, urban, and agro-ecosystem) and soil types (Haplic Chernozem, Haplic Luvisol, Haplic Stagnosol) with a dependence on the influence of quantity and quality of soil organic matter and the particle size distribution on fraction composition of soil aggregates were compared. Soils had different productive capacity and particle size distribution. The most favourable soil structure was in the agro-ecosystem, then in forest, meadow, and urban ecosystem. The worst soil structure was in Haplic Stagnosol. An important indicator in assessing of ecosystem influence, water-resistant macro-aggregates of the $0.5-1 \mathrm{~mm}$ size fraction seems to be. This fraction was the only one which was statistically significantly influenced by the ecosystem, and also the only one which was

Key words: soil organic matter, soil structure, ecosystem

Changes in land use had influence on the vegetation and the soil. The conversion of forest and meadow to the arable land leads primarily to a reduction in the content of soil organic carbon and changes in soil aggregate stability (Singh \& Singh 1996). Analyses of dynamics in agro-ecosystems are difficult because of their complicated internal interactions between individual components (Tornquist et al. 2009). In agro-ecosystems, the maintenance of organic carbon amount is a major role in reducing of soil degradation (Bhattacharyya et al. 2009). Urban ecosystems are complicated areas composed of different ecosystems, located close to each other and not statistically significantly influenced by the soil type. This fraction also was not influenced either with the quantity and quality of soil organic matter, or with the particle size distribution. The quantity of soil organic matter is reflected in relation to the fractional composition of dry-sieved aggregates and its quality in relation to waterresistant aggregates. Large fractions of water-resistant macro-aggregates were in positive correlation with $\mathrm{C}: \mathrm{N}$ ratio, the amount of extracted humus substances, or stability and quality of humic acids; while smaller fractions were in negative correlation just with these parameters. Clay and silt fractions had a positive influence on waterresistant macro-aggregates formation, while sand fraction had negative and vice versa.

influenced by each other (Vrščaj et al. 2009). The soil structure in individual ecosystems is a reflection of many factors, while the particle size distribution and the quantity and quality of soil organic matter are crucial. The organic matter is considered to be an essential element in the formation of aggregates (Zeytin \& Baran 2003) and on the contrary, the formation of aggregates contributes to the stabilization of soil organic matter by its physical protection in aggregates (Balabane \& Plante 2004). The relationship between the soil structure and organic matter is dynamic (Bonde et al. 1988), while the stability of soil aggregates depends not only on the quantity 
but also the quality of organic substance inputs (Tisdall \& Oades 1982). The rate of soil organic matter accumulation and its fractions also depends on the particle size distribution (Amelung et al. 1998; Tobiašová 2011a; Tobiašová 2011b). Clay is bound with large proportion of organic substances, but also supports the formation of stabile macro-aggregates (Jastrow 1996). The objectives of this study were as follows: (i) comparison of the soil structure in different ecosystems and soil types, (ii) assessment of the quantity and quality of soil organic matter, and (iii) particle size distribution influence on fraction composition of macro-aggregates.

\section{MATERIALS AND METHODS}

Experiment includes the soil types Haplic Chernozem, Haplic Luvisol, Haplic Stagnosol (WRB 2006), which have not only different productive capacity, but also different particle size distribution (Table 1). They are the soils of lowland and hilly areas (Figure 1), which are largely cultivated and thus have the potential for carbon sequestration. The experiment includes soils of four different ecosystems (forest, meadow, urban, and agro-ecosystem).

\section{Characteristics of the territory}

The sampling places on the Haplic Chernozem are situated in Močenok, which is located on the northern edge of the Danube Basin. Its geological structure is characterized by neogene strata, consisting of claystones, sandstones, and andesites, which are covered by younger rocks of quaternary, represented by different fluvial and aeolian sediments. The relief is wavy hilly, formed by terraces of Vah and Nitra rivers. The terraces are covered with loess, loessial loams, and aeolian sands (Pristaš et al. 2000). The area is situated in a warm climate area with an average annual temperature of $9.8^{\circ} \mathrm{C}$ and with the average rainfall of $568 \mathrm{~mm}$ per year. Natural vegetation consists mostly of oak-ash-elmalder forests, and along the river there are willowpoplar forests and floodplain forests. On elevated surfaces and dunes, mainly xerophilous communities with oak-elm forest exist (Korec et al. 1997). Dominant crops in the agro-ecosystem were: cereals (70\%), root crops $(20 \%)$, oil crops $(5 \%)$, and the rest were other crops.

The sampling places on the Haplic Luvisol are situated in Vel'ké Zálužie, which is located on the Danube Lowland, on the whole Danube hilly area, on the Nitra hilly area. Its geological structure is

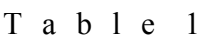

Chemical and physical properties of studied soils

\begin{tabular}{|c|c|c|c|c|c|c|c|c|}
\hline \multirow{2}{*}{ Soil type } & \multirow{2}{*}{ Ecosystem } & $\mathrm{pH} / \mathrm{KCl}$ & $\mathrm{CO}_{3}^{2-}$ & $\mathrm{TOC}^{5}$ & \multirow{2}{*}{$\begin{array}{c}\mathrm{CEC}^{6} \\
{[\mathrm{mmol} / \mathrm{kg}]}\end{array}$} & clay & silt & sand \\
\hline & & \multicolumn{3}{|c|}{$[\%]$} & & \multicolumn{3}{|c|}{$[\%]$} \\
\hline \multirow{4}{*}{$\begin{array}{l}\text { Haplic } \\
\text { Chernozem }\end{array}$} & $\mathrm{FE}^{1}$ & 5.89 & 0.38 & 2.232 & 339.91 & 14.61 & 32.34 & 53.05 \\
\hline & $\mathrm{ME}^{2}$ & 7.38 & 6.20 & 2.210 & 489.80 & 15.50 & 39.01 & 45.49 \\
\hline & $\mathrm{UE}^{3}$ & 7.44 & 6.06 & 2.299 & 491.08 & 12.22 & 49.75 & 38.03 \\
\hline & $\mathrm{AE}^{4}$ & 6.82 & 6.13 & 2.070 & 290.22 & 17.44 & 50.13 & 32.43 \\
\hline \multirow{4}{*}{$\begin{array}{l}\text { Haplic } \\
\text { Luvisol }\end{array}$} & $\mathrm{FE}$ & 6.61 & 0.40 & 1.395 & 195.08 & 10.77 & 23.00 & 66.23 \\
\hline & $\mathrm{ME}$ & 7.63 & 6.20 & 1.577 & 495.51 & 12.96 & 49.47 & 37.57 \\
\hline & UE & 7.84 & 6.20 & 1.400 & 489.81 & 11.44 & 63.53 & 25.03 \\
\hline & $\mathrm{AE}$ & 7.33 & 7.24 & 0.889 & 143.29 & 13.05 & 27.36 & 59.60 \\
\hline \multirow{4}{*}{$\begin{array}{l}\text { Haplic } \\
\text { Stagnosol }\end{array}$} & $\mathrm{FE}$ & 4.23 & 0.10 & 0.725 & 125.46 & 16.75 & 58.01 & 25.24 \\
\hline & $\mathrm{ME}$ & 5.13 & 0.10 & 0.977 & 175.43 & 25.17 & 36.95 & 37.88 \\
\hline & $\mathrm{UE}$ & 4.94 & 0.10 & 0.773 & 191.73 & 29.87 & 26.23 & 43.90 \\
\hline & $\mathrm{AE}$ & 5.54 & 0.16 & 1.162 & 204.01 & 25.99 & 43.64 & 30.37 \\
\hline
\end{tabular}

${ }^{1} \mathrm{FE}$ - forest ecosystem, ${ }^{2} \mathrm{ME}$ - meadow ecosystem, ${ }^{3} \mathrm{UE}$ - urban ecosystem, ${ }^{4} \mathrm{AE}$ - agro-ecosystem, ${ }^{5} \mathrm{TOC}-$ total organic carbon, ${ }^{6} \mathrm{CEC}$ - cation exchangeable capacity 
characterized by neogene sediments - loess. Neogene bedrock consists of brackish and lake sediments (clays, gravels, and sands). The relief is formed by river terraces, which are a transition from the river floodplains to the hilly area. Wide and shallow valleys of streams divide the hilly area on the system of crests and plateaus (Hók et al. 2001). The area is situated in a warm climate with an average annual temperature of $9.3^{\circ} \mathrm{C}$ and with the average rainfall of $607 \mathrm{~mm}$ per year (Korec et al. 1997). The Nitra hilly area is highly deforested. In the lower parts oak forests exist, and in higher parts beech forests are presented. Dominant crops in the agro-ecosystem were: cereals $(60 \%)$, oil crops $(30 \%)$, forage $(5 \%)$ and the rest were other crops.

The sampling places on the Haplic Stagnosol are situated in Hrachovo, which is located on the Juhoslovenská basin, in the catchment area of the Ipel' river. Its geological structure is characterized by marine and brackish sediments (sandstones, sands, clays, marls, and at the edges there are gravels and limestone). The neogene sediments are covered by fluvial - alluvial deposits. The relief is formed with hilly areas and floodplains. River erosion of neogene sediments conditioned the formation of higher lying hilly areas (Šajgalík et al. 1986). The area is situated in a warm climate with an average annual temperature of $8.8^{\circ} \mathrm{C}$ and with the average rainfall of $640 \mathrm{~mm}$ per year (Korec et al. 1997). In the lower parts the forest, oak, hornbeam and acacia are presented. Dominant crops in the agro-ecosystem were: cereals $(60 \%)$, forage $(20 \%)$, oil crops $(15 \%)$ and the rest were other crops.

\section{Soil samples and analytical methods used}

The soil samples for determination of chemical and physical properties were collected in three replicates to a depth of $0.3 \mathrm{~m}$. The soil samples were dried in a constant temperature-room and ground. The soil samples for the determination of soil structure were dried only after being homogenized

The physical analyses included particle size distribution according to pipette methods (Fiala et al. 1999) and soil structure by determination of drysieved aggregates and water-resistant aggregates according to Bakšejevev method. The soil structure was assessed by the aggregate stability index (Henin et al. 1969), the coefficient of vulnerability (Valla et al. 2000), the index of crusting based on particle size distribution (FAO 1979) and soil organic matter and the critical soil organic matter content (Pieri 1991). The total organic carbon was determined by wet combustion (Orlov \& Grišina 1981), the total nitrogen was determined by the Kjeldahl method (Fiala et al. 1999), group composition of humus substances was determined by the Belčikova and Kononova method (Orlov \& Grišina 1981), optical parameters of humus substances by determining of colour quotients of humus substances and humic acids measured at wavelength 425 and $650 \mathrm{~nm}$ (Orlov \& Grišina 1981), and also the $\mathrm{pH}$ of the soil was potentiometrically measured and cation exchange capacity was determined (Fiala et al. 1999). Parameters characterizing the quality of humus, like the ratio of carbon of humic acids to carbon of fulvic acids, and $\mathrm{C}: \mathrm{N}$ ratio, were also calculated.

The obtained data were analysed using Statgraphic Plus statistical software. A multifactor ANOVA model was used for individual treatment comparison at $P<0.05$, with separation of the means by Tukey multiple-range test. Correlation analysis was used to determine the relationships between the quantity and quality of soil organic matter and the particle size distribution and parameters of soil structure parameters. Significant correlation coefficients were tested at $P<0.05$ and $P<0.01$.

\section{RESULTS AND DISCUSSION}

Formation of aggregates in soil is influenced by several factors that are specific for each soil. Aggregate dynamics is most intensively influenced by the soil organic matter and the particle size distribution. Formation of dry-sieved aggregates was mainly influenced by the amount of soil organic matter. Positive correlations were observed mainly in the range of $1-5 \mathrm{~mm}$ size fractions (Table 2). In the case of the largest fraction of macro-aggregates, this correlation was negative. In larger aggregates, the amount of soil organic matter is really higher, but is subject to larger changes as well, especially rapid mineralization (Six et al. 2001). In case of the largest fraction of dry-sieved macro-aggregates, positive correlation just with clay fraction was recorded (Table 3). Clay is able to bind a lot of water, which supports 
the formation of so-called pseudo-aggregates. If this water is enriched with dissolved carbonates, by drying, links between mineral particles get created, and thus the aggregate hold together. The carbonate content (Table 1) was higher in the agro-ecosystem, because in addition to their natural presence, there was source liming of the soil as well. This shows the highest proportion of the largest fraction of drysieved aggregates in the agro-ecosystem only. Organic matter in the case of larger dry-sieved aggregates is quickly oxidized, because it has the lack of physical protection; so in case of its higher proportion such aggregate is disrupted. A negative correlation with the amount of organic matter was recorded in the case of micro-aggregates (Table 2). But for micro-aggregates, the lower content of organic matter is characteristic (Sohi et al. 2001), because on their formation mainly the mineral components of soil participate and the cement agent in them are primarily $\mathrm{R}_{2} \mathrm{O}_{3}$ (Duiker et al. 2003) and stabilized organic substances, especially humic acids, which shows a positive correlation between their content and dry-sieved micro-aggregates (Table 2).

In relation to the stability of soil aggregates, mainly the proportion of water-resistant macro-ag- gregate fractions is important. In their formation, the quality of soil organic matter plays an important role. Sisák (1994) considers the water-resistant aggregates of the $0.5-3 \mathrm{~mm}$ size fraction such as agronomically the most valuable aggregate. In our case, a positive correlation between the quality of soil organic matter and water-resistant macro-aggregates of the 1-3 $\mathrm{mm}$ size fraction was recorded. The $0.5-1 \mathrm{~mm}$ size fraction of water-resistant macro-aggregates, which is still considered to be the most valuable fraction, was not influenced at all - neither through the quality of soil organic matter (Table 2), nor the particle size distribution of soil (Table 3). In case of the studied soil types, the statistically significant differences in all fractions of water-resistant macro-aggregates $(0.5-1 \mathrm{~mm})$ were not recorded (Table 4). On the contrary, in case of ecosystems, differences in proportion of water-resistant aggregate fractions were not recorded, in addition to just fraction of $0.5-1 \mathrm{~mm}$. Therefore, this fraction of macro-aggregates seems to be the most suitable for assessing the influence of land use on soil structure. In this case, the $0.5-1 \mathrm{~mm}$ size fraction had the highest proportion in the agro-ecosystem, in which agronomically the most valuable macro-aggregates

T a b $\quad$ b 1 e 2

Correlations between the parameters of soil organic matter and dry-sieved and water-resistant aggregates

\begin{tabular}{|l|c|c|c|c|c|c|c|c|c|c|}
\hline Aggregates & $\mathrm{TOC}^{1}$ & $\mathrm{NT}^{2}$ & $\mathrm{C}: \mathrm{N}$ & $\mathrm{C}_{\mathrm{HS}}{ }^{3}$ & $\mathrm{C}_{\mathrm{HA}}{ }^{4}$ & $\mathrm{C}_{\mathrm{FA}}{ }^{5}$ & $\mathrm{C}_{\mathrm{HA}}: \mathrm{C}_{\mathrm{FA}}{ }^{6}$ & $\mathrm{Q}_{\mathrm{HS}}{ }^{7}$ & $\mathrm{Q}_{\mathrm{HA}}{ }^{8}$ \\
\hline Water-resistant \\
\hline $2-3 \mathrm{~mm}$ & -0.036 & -0.214 & $0.456^{+}$ & $0.486^{+}$ & 0.251 & $0.448^{+}$ & -0.205 & $0.526^{+}$ & $0.517^{+}$ \\
$1-2 \mathrm{~mm}$ & -0.062 & -0.341 & $0.669^{++}$ & $0.488^{+}$ & $0.480^{+}$ & 0.379 & -0.013 & 0.383 & $0.471^{+}$ \\
$0.5-1 \mathrm{~mm}$ & -0.100 & -0.131 & -0.063 & -0.186 & 0.116 & -0.213 & 0.115 & -0.315 & -0.315 \\
$0.25-0.5 \mathrm{~mm}$ & -0.304 & -0.159 & $-0.518^{+}$ & -0.293 & 0.065 & -0.347 & 0.269 & -0.231 & -0.344 \\
$<0.25 \mathrm{~mm}$ & 0.241 & 0.374 & -0.372 & $-0.574^{++}$ & -0.336 & $-0.523^{+}$ & 0.331 & $-0.567^{++}$ & $-0.495^{+}$ \\
\hline Dry-sieved & -0.387 & $-0.505^{+}$ & 0.290 & $0.501^{+}$ & 0.342 & 0.429 & -0.193 & $0.501^{+}$ & $0.446^{+}$ \\
\hline $7-10 \mathrm{~mm}$ & 0.052 & 0.133 & -0.164 & -0.062 & $-0.479^{+}$ & 0.086 & -0.273 & 0.060 & 0.021 \\
$5-7 \mathrm{~mm}$ & $0.534^{+}$ & $0.649^{++}$ & -0.132 & -0.360 & $-0.738^{++}$ & -0.148 & -0.125 & -0.291 & -0.172 \\
$3-5 \mathrm{~mm}$ & $0.559^{++}$ & $0.504^{+}$ & 0.218 & $-0.459^{+}$ & -0.259 & -0.401 & 0.298 & $-0.437^{+}$ & -0.366 \\
$1-3 \mathrm{~mm}$ & 0.032 & -0.013 & 0.026 & -0.111 & 0.329 & -0.221 & 0.286 & -0.188 & -0.235 \\
$0.5-1 \mathrm{~mm}$ & 0
\end{tabular}

${ }^{+} P<0.05,{ }^{++} P<0.01,{ }^{1} \mathrm{TOC}-$ total organic carbon, ${ }^{2} \mathrm{NT}-$ total nitrogen, ${ }^{3} \mathrm{C}_{\mathrm{HS}}-$ carbon of humus substances, ${ }^{4} \mathrm{C}_{\mathrm{HA}}$ - carbon of humic substances, ${ }^{5} \mathrm{C}_{\mathrm{FA}}-$ carbon of fulvic acids, ${ }^{6} \mathrm{C}_{\mathrm{HA}}: \mathrm{C}_{\mathrm{FA}}-$ ration of carbon of humic acids to carbon of fulvic acids, ${ }^{7} \mathrm{Q}_{\mathrm{HS}}-$ colour quotient of humus substances, ${ }^{8} \mathrm{Q}_{\mathrm{HA}}-$ colour quotient of humic acids 
of the $0.5-3 \mathrm{~mm}$ size fraction had also the highest proportion (52.30\%). Emadi et al. (2009) also reported that ploughed soils have higher proportion of the micro-aggregates and small macro-aggregates $(<0.5 \mathrm{~mm})$. According to Whalen and Chang (2002), the increased proportion of small aggregates $(<1.2 \mathrm{~mm})$ is an important indicator of soil degradation. Relatively balanced content of the $0.5-1 \mathrm{~mm}$ size fraction was in the meadow and urban ecosystem, because in both cases it was grassland, indicating a higher influence of vegetation cover than anthropogenic factors influencing the soil properties in urban ecosystem. The lowest content of the 0.5-1 mm size fraction was in the forest ecosystem, but the lowest total content of agronomically the most valuable macro-aggregates was not recorded in this ecosystem. The $0.5-3 \mathrm{~mm}$ size fraction of water-resistant aggregates had nearly the same proportion in the forest ecosystem $(45.85 \%)$ as in meadow (43.31\%) and urban ecosystems (41.25\%). Agronomically the most valuable aggregates, however, do not necessarily mean the best stability of soil structure, or higher sequestration of carbon in soil.

To assess the overall condition of the soil structure, we can use several parameters, which reflect not only the main factors involved in the formation of stabile soil structure, but also take into account the internal mechanisms operating in aggregate dynamics. In relation to the soil type, statistically significant differences in the case of aggregate stability index $\left(\mathrm{S}_{\mathrm{w}}\right)$ and critical soil organic matter content $\left(S_{t}\right)$ were recorded (Table 4). In relation to the ecosystem, the highest $\mathrm{S}_{\mathrm{w}}$ was recorded in the forest ecosystem. Aggregate dynamics is a reflection of the chemical composition of plant residues. In forest litter, phenols and polyphenols, which are precursors of humus substances (Martens 2000) and lignin are dominated, and support the aggregate formation (Magill \& Aber 1998). Second the most stabile aggregates were in the agro-ecosystem, with the application of farmyard manure, which is a source of stabile humus substances and the number of microorganisms. According to Debosz et al. (2002), the carbohydrates of microbial origin resist the degradation better than do the carbohydrates of plant origin. In the meadow ecosystem, an important source of organic matter is mainly root exudates, which belong to the labile fraction of soil organic matter. According to Tisdal and Oades (1982), polysaccharides are easily mineralizable and act rather as temporary

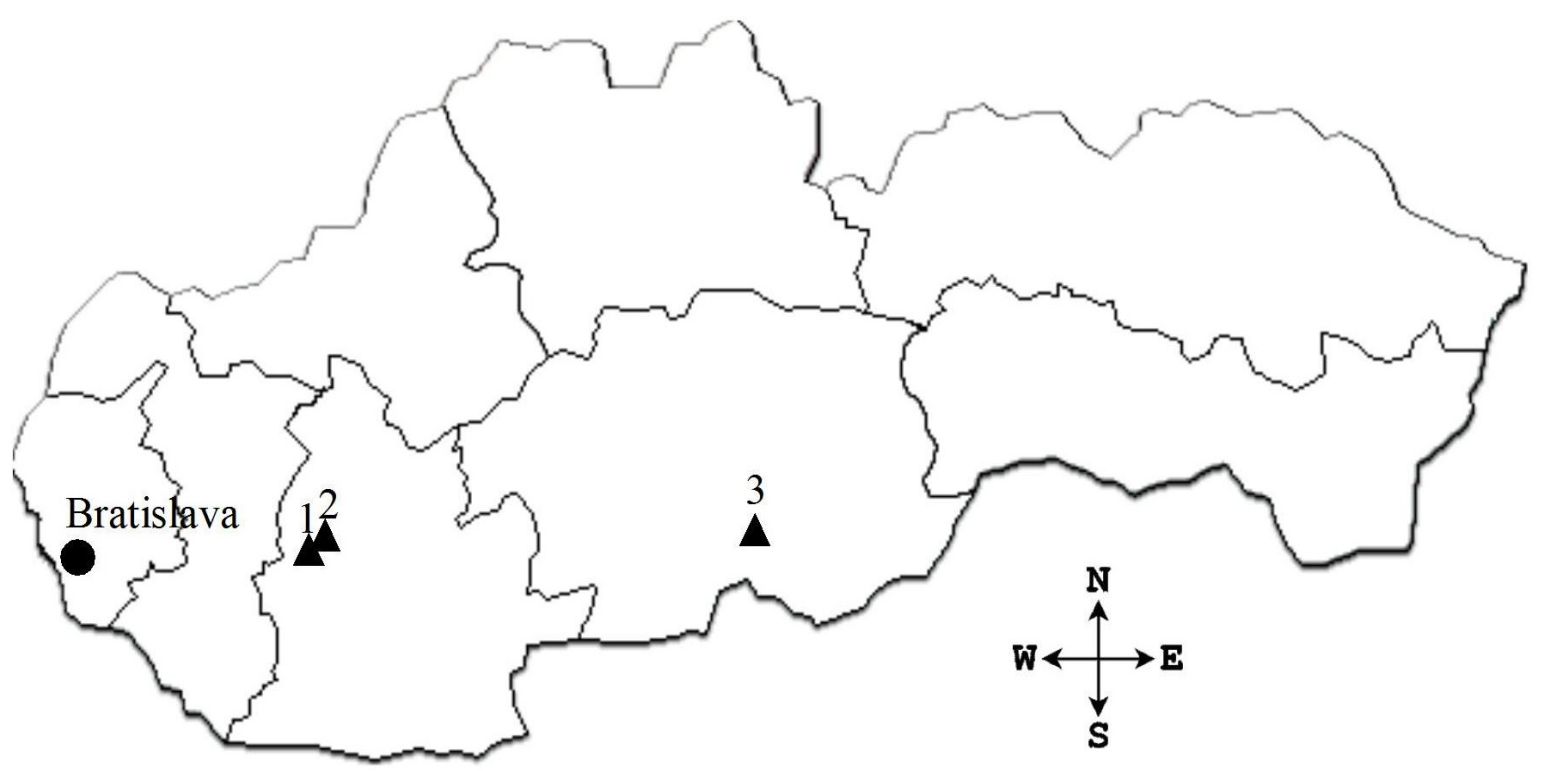

Figure 1. Localities of the soil: 1 - Haplic Chernozem, 2 - Haplic Luvisol, 3 - Haplic Satgnosol 


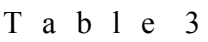

Correlations between the particle size distribution and dry-sieved and water-resistant aggregates

\begin{tabular}{|c|c|c|c|c|c|c|}
\hline \multirow{2}{*}{ Aggregates } & $0.25-2$ & $0.05-0.25$ & $0.01-0.05$ & $0.001-0.01$ & $<0.001$ & $<0.01$ \\
\hline & \multicolumn{6}{|c|}{$[\mathrm{mm}]$} \\
\hline \multicolumn{7}{|l|}{ Water-resistant } \\
\hline $2-3 \mathrm{~mm}$ & 0.023 & $-0.679^{++}$ & 0.117 & $0.540^{+}$ & $0.655^{++}$ & $0.824^{++}$ \\
\hline $1-2 \mathrm{~mm}$ & 0.152 & $-0.709^{++}$ & 0.039 & $0.560^{++}$ & $0.620^{++}$ & $0.680^{++}$ \\
\hline $0.5-1 \mathrm{~mm}$ & 0.086 & 0.323 & -0.178 & -0.281 & -0.263 & -0.426 \\
\hline $0.25-0.5 \mathrm{~mm}$ & -0.136 & $0.822^{++}$ & -0.261 & $-0.642^{++}$ & $-0.477^{+}$ & $-0.590^{++}$ \\
\hline$<0.25 \mathrm{~mm}$ & -0.279 & $0.467^{+}$ & 0.245 & -0.351 & $-0.544^{+}$ & $-0.653^{++}$ \\
\hline \multicolumn{7}{|l|}{ Dry-sieved } \\
\hline $7-10 \mathrm{~mm}$ & -0.275 & -0.400 & 0.078 & $0.584^{++}$ & $0.631^{++}$ & $0.718^{++}$ \\
\hline $5-7 \mathrm{~mm}$ & $-0.457^{+}$ & 0.163 & 0.110 & 0.156 & 0.128 & 0.113 \\
\hline $3-5 \mathrm{~mm}$ & -0.272 & -0.205 & $0.510^{+}$ & 0.182 & -0.082 & -0.057 \\
\hline $1-3 \mathrm{~mm}$ & -0.030 & -0.318 & $0.511^{+}$ & 0.010 & -0.135 & -0.103 \\
\hline $0.5-1 \mathrm{~mm}$ & $0.443^{+}$ & 0.206 & -0.297 & -0.425 & -0.323 & -0.371 \\
\hline $0.25-0.5 \mathrm{~mm}$ & 0.393 & $0.477^{+}$ & $-0.509^{+}$ & $-0.517^{+}$ & -0.365 & -0.427 \\
\hline$<0.25 \mathrm{~mm}$ & 0.416 & 0.253 & $-0.541^{+}$ & -0.261 & -0.117 & -0.177 \\
\hline
\end{tabular}

T $\begin{array}{llllllllll} & \text { a } & \text { b } & 1 & \text { e } & 4\end{array}$

Statistical evaluation of dry-sieved and water-resistant aggregates in soil types and ecosystems

\begin{tabular}{|c|c|c|c|c|c|c|c|c|c|}
\hline \multirow{2}{*}{ Factors } & $2-3 \mathrm{~mm}$ & $1-2 \mathrm{~mm}$ & $0.5-1 \mathrm{~mm}$ & $0.25-0.5 \mathrm{~mm}$ & $<0.25 \mathrm{~mm}$ & $\mathrm{~S}_{\mathrm{w}}{ }^{8}$ & $\mathrm{~K}_{\mathrm{v}}{ }^{9}$ & \multirow{2}{*}{$\begin{array}{l}\mathrm{S}_{\mathrm{t}}^{10} \\
{[\%]}\end{array}$} & \multirow{2}{*}{$\mathrm{I}_{\mathrm{c}}{ }^{11}$} \\
\hline & \multicolumn{7}{|c|}{$[\%]$} & & \\
\hline \multicolumn{10}{|c|}{ Soil type } \\
\hline $\mathrm{HC}^{1}$ & $11.72^{\mathrm{a}}$ & $18.65^{\mathrm{b}}$ & $18.25^{\mathrm{a}}$ & $11.51^{\mathrm{a}}$ & $21.52^{\mathrm{b}}$ & $1.54^{\mathrm{a}}$ & $0.30^{\mathrm{a}}$ & $6.15^{\mathrm{c}}$ & $0.87^{\mathrm{a}}$ \\
\hline $\mathrm{HL}^{2}$ & $6.24^{\mathrm{a}}$ & $10.01^{\mathrm{a}}$ & $20.95^{\mathrm{a}}$ & $29.07^{b}$ & $25.91^{\mathrm{b}}$ & $2.03^{b}$ & $0.26^{\mathrm{a}}$ & $4.29^{\mathrm{b}}$ & $1.06^{\mathrm{a}}$ \\
\hline $\mathrm{HS}^{3}$ & $20.36^{\mathrm{b}}$ & $25.31^{\mathrm{c}}$ & $14.04^{\mathrm{a}}$ & $7.11^{\mathrm{a}}$ & $7.21^{\mathrm{a}}$ & $1.36^{\mathrm{a}}$ & $0.37^{\mathrm{a}}$ & $2.61^{\mathrm{a}}$ & $1.15^{\mathrm{a}}$ \\
\hline \multicolumn{10}{|c|}{ Ecosystem } \\
\hline $\mathrm{FE}^{4}$ & $15.92^{\mathrm{a}}$ & $19.28^{\mathrm{a}}$ & $10.65^{\mathrm{a}}$ & $12.67^{\mathrm{a}}$ & $13.24^{\mathrm{a}}$ & $2.10^{\mathrm{b}}$ & $0.25^{\mathrm{a}}$ & $5.77^{\mathrm{bc}}$ & $0.88^{\mathrm{a}}$ \\
\hline $\mathrm{ME}^{5}$ & $14.11^{\mathrm{a}}$ & $15.85^{\mathrm{a}}$ & $13.35^{\mathrm{ab}}$ & $9.25^{\mathrm{a}}$ & $17.28^{\mathrm{a}}$ & $1.37^{\mathrm{a}}$ & $0.32^{\mathrm{a}}$ & $3.48^{\mathrm{ab}}$ & $1.28^{\mathrm{a}}$ \\
\hline $\mathrm{UE}^{6}$ & $14.01^{\mathrm{a}}$ & $14.32^{\mathrm{a}}$ & $12.92^{\mathrm{ab}}$ & $10.87^{\mathrm{a}}$ & $20.95^{\mathrm{a}}$ & $1.41^{\mathrm{a}}$ & $0.38^{\mathrm{a}}$ & $2.25^{\mathrm{a}}$ & $1.22^{\mathrm{a}}$ \\
\hline $\mathrm{AE}^{7}$ & $11.34^{\mathrm{a}}$ & $19.12^{\mathrm{a}}$ & $21.83^{\mathrm{b}}$ & $19.70^{\mathrm{a}}$ & $19.00^{\mathrm{a}}$ & $1.66^{\mathrm{a}}$ & $0.39^{\mathrm{a}}$ & $6.82^{\mathrm{c}}$ & $0.77^{\mathrm{a}}$ \\
\hline
\end{tabular}

${ }^{1} \mathrm{HC}$ - Haplic Chernozem, ${ }^{2} \mathrm{HL}$ - Haplic Luvisol, ${ }^{3} \mathrm{HS}$ - Haplic Stagnosol, ${ }^{4} \mathrm{FE}$ - forest ecosystem, ${ }^{5} \mathrm{ME}$ - meadow ecosystem, ${ }^{6} \mathrm{UE}$ - urban ecosystem, ${ }^{7} \mathrm{AE}$-agro-ecosystem, ${ }^{8} \mathrm{~S}_{\mathrm{w}}$ - aggregate stability index, ${ }^{9} \mathrm{~K}_{\mathrm{v}}-$ coefficient of vulnerability, ${ }^{10} \mathrm{~S}_{\mathrm{t}}$ - critical soil organic matter content, ${ }^{11} \mathrm{I}_{\mathrm{c}}-$ index of crusting. Different letters (a, b, and c), between the factors, show statistically significant difference $P<0.05$ - Tukey test 
components for the formation of aggregates. In individual ecosystems, the influence of vegetation cover on the stability of soil aggregates was shown. The highest Sw was in Haplic Luvisol, although the sand fraction had the highest proportion in it. Fine sand fraction was in negative correlation with larger fractions of water-resistant macro-aggregates (1-3 mm) and in positive correlation with smaller macro-aggregates $(0.25-0.5 \mathrm{~mm})$ and micro-aggregates. In Haplic Luvisol, the content of these fractions was the highest (Table 3). On the contrary, clay and fine silt fractions were in positive correlation with larger macro-aggregates $(1-3 \mathrm{~mm})$ and with small fractions of macro-aggregates $(0.25-0.5 \mathrm{~mm})$, and in negative correlation with micro-aggregates. Haplic Luvisol had the highest content of carbonates and the highest value of $\mathrm{pH} / \mathrm{KCl}$.

According to the parameter of St, the best soil structure was in Haplic Chernozem; in spite of that, it was evaluated as an unstable structure with a risk of soil degradation. In the case of Haplic Luvisol and Haplic Stagnosol, there is loss of soil structure with high susceptibility to erosion. In relation to the ecosystem, the soil structure in the agro-ecosystem and forest ecosystem can be evaluated as the best soil structure, although it is also an unstable structure with a risk of soil degradation.

\section{CONCLUSION}

The most favourable soil structure was in the agro-ecosystem, then in forest, meadow, and urban ecosystem. The soil structure of the Haplic Stagnosol was the worst. Water-resistant macro-aggregates of the $0.5-1 \mathrm{~mm}$ size fraction seem to be an important indicator for assessing the ecosystem influence on soil. This fraction was the only one, which was statistically significantly influenced by the ecosystem and the only one, which was not statistically significantly influenced by the soil type. This fraction was not influenced either with the quantity and quality of soil organic matter, or with the particle size distribution.

The quantity of soil organic matter is reflected mainly in relation to the fractional composition of dry-sieved aggregates and its quality in relation to water-resistant aggregates. Larger fractions
(> $1 \mathrm{~mm}$ ) of water-resistant macro-aggregates were in positive correlation with $\mathrm{C}: \mathrm{N}$ ratio, the amount of extracted humus substances, and the stability and quality of humic acids; while smaller fractions $(<0.5 \mathrm{~mm})$ were in negative correlation just with these parameters.

Clay and silt fractions influenced the formation of larger water-resistant macro-aggregates positively, while sand fraction negatively, and vice versa.

Acknowledgments. This project was supported by the Scientific Grant Agency of the Ministry of Education of the Slovak Republic and the Slovak Academy of Sciences (nos. 1/0124/13 and 1/0300/11).

\section{REFERENCES}

AMELUNG, W. - ZEECH, W. - ZHANG, X. - FOLLETT, H. - TIESSEN, E. - KNOX, E. - FLACH, W. 1998. Carbon, nitrogen and sulfur pools in particlesize fractions as influenced by climate. In Soil Science Society of America Journal, vol. 62, 1998, no. 1, pp. 172-181. DOI:10.2136/sssaj 1998.0361599500 $6200010023 \mathrm{x}$

BAlabAne, M. - PlAnTE, A.F. 2004. Aggregation and carbon storage in silty soil using physical fractionation techniques. In European Journal of Soil Science, vol. 55, 2004, no. 2, pp. 415-427. DOI: $10.1111 / \mathrm{j} .1351-0754.2004 .0608 . \mathrm{x}$

BHATTACHARYYA, R. - PRAKASH, V. - KUNDU, S. - SRIVASTVA, A.K. - GUPTA, H.S. 2009. Soil aggregation and organic matter in a sandy clay loam soil of the Indian Himalayas under different tillage and crop regimes. In Agriculture Ecosystem and Environment, vol. 132, no. 1-2, 2009, pp. 126-134.

BONDE, T.A. - SCHNÜRER, J. - ROSSWALL, T. 1988. Microbial biomass as a fraction of potentially mineralizable nitrogen in soils from long-term field experiments. In Soil Biology and Biochemistry, vol. 20, 1988, no. 4, pp. 447-452.

DEBOSZ, K. - PETERSON, S.O. - KURE, L.K. AMBUS, P. 2002. Evaluating effects on sewage sludge and household compost on soil physical, chemical and microbiological properties. In Aplied Soil Ecology, vol. 19, 2002, pp. 237-48.

DUIKER, S.W. - RHOTON, F.E. - TORRENT, J. - SMECK, N.E. - LAL, R. 2003. Iron (hydr)oxide crystallinity effects on soil aggregation. In Soil Science Society of America Journal, vol. 67, 2003, no. 2, pp. 606-611. DOI:10.2136/sssaj2003.6060

EMADI, M. - BAGHERNEJAD, M. - MEMARIAN, H.R. 2009. Effect of land-use change on soil fertility characteristics within water-stable aggregates of two cultivated soils in northern Iran. In Land Use Policy, vol. 26, 2009, no. 2, pp. 452-457. 
FIALA, K. - KOBZA, J. - MATÚŠKOVÁ, L. - BREČKOVÁ, V. - MAKOVNÍKOVÁ, J. - BARANČÍKOVÁ, G. - BÚRIK, V. - LITAVEC, T. - HOUŠKOVÁ, B. CHROMANIČOVÁ, A. - VÁRADIOVÁ, D. - PECHOVÁ, B. 1999. Záväzné metódy rozborov pôd. Čiastkový monitorovaci system - PÔDA [Approved methods of soil analyses. Partial monitoring system - Soil] Bratislava : VÚPOP, 1999. pp. 142.

FAO. 1979. Soil Survey Investigation for Irrigation. Rome : FAO, 1979. pp.188.

HENIN, S. - GRAS, R. - JUNGERIUS, P.D. 1969. Le profil cultural: I'état psysique du so let ses consequences agronomiques. Paris : Masson, 1969. pp. 322.

HÓK, J. - KAHAN, Š. - AUBRECHT, R. 2001. Geology of Slovakia. Bratislava : UK, 2001. 48 pp. ISBN 80223-1592-3

IUSS Working Group WRB. 2006. World reference base for soil resources. 2006. World Soil Resources Reports No. 103, Roma : FAO, pp. 145.

JASTROW, J.D. 1996. Soil aggregate formation and the accrual of particulate and mineral-associated organic matter. In Soil Biology and Biochemistry, vol. 28, 1996, no. $4-5$, pp. $665-676$.

KOREC, P. - LAUKO, V. - TOLMÁČI, L. - ZUBRICKÝ, G. - MIČIETOVÁ, E. 1997. Kraje a okresy Slovenska. Nové administratívne členenie [Counties and districs of Slovakia]. Bratislava: Q111, 1997. $387 \mathrm{pp}$.

MAGILL, A.H. - ABER, J.D. 1998. Long-term effects of experimental nitrogen additions on foliar decay and humus formation in forest ecosystems. In Plant Soil, vol. 203, 1998, pp. 301-311.

MARTENS, A.D. 2000. Plant residue biochemistry regulates soil carbon cycling and carbon sequestration. In Soil Biology and Biochemistry, vol. 32, 2000, no. 3, pp. 361-369.

PIERI, C. 1991. Fertility of soils: A future for farming in the West African savannah. Berlin : Springer-Verlag, 1991. pp. 348.

ORLOV, D.S. - GRIŠINA, L.A. 1981. Praktikum po chimiji gumusa. Moskva: IMU, 1981. 272 pp.

PRISTAŠ, J. - ELEČKO, M. - MAGLAY, J. - FORDINÁL, K. - ŠIMON, L. - GROSS, P. - POLÁK, M. - HAVRILA, M. - IVANIČKA, J. - HATÁR, J. - VOZÁR, J. - MELLO, J. - NAGY, A. 2000. Geologická mapa Podunajskej nižiny - Nitrianska pahorkatina 1:50000 [Geological map of Danube Lowland - Nitra hilly area]. Bratislava : Ministry of environment SR, State geological institute of Dionyz Stur, 2000.

SINGH, S. - SINGH, J.S. 1996. Water-stable aggregates and associated organic mater in forest, savanna, and cropland soils of a seasonally dry tropical region. In Indian Biological Fertility of Soils, vol. 22, 1996, pp. 76-82.

SISÁK, P. 1994. Study the effect of different management systems on composition of micro-aggregates and water- resistant macro-aggregates of Haplic Luvisol. In News about increasing of productive ability of soils. Nitra : VŠP - VÚPÚ, 1994. pp. 53-56.

SIX, J. - GUGGENBERGER, G. - PAUSTIAN, K. - HAUMAIER, L. - ELLIOT, E.T. - ZECH, W. 2001. Sources and composition of soil organic matter fractions between and within soil aggregates. In European Journal of Soil Science, vol. 52, 2001, no. 4, pp. 607-618. DOI: 10.1046/j.1365-2389.2001.00406.x

SOHI, S.P. - MAHIEU, N. - ARAH, J.R.M. - POWLSON, D.S. - MADARI, B. - GAUNT, J.L. 2001. A procedure for isolating soil organic matter fractions for modeling. In Soil Science Society of America Journal, vol. 65 , 2001, no. 4, pp. 1121-1128. DOI:10.2136/ sssaj2001.6541121x

ŠAJGALÍK, J. - ČABALOVÁ, D. - SCHÜTZNEROVÁ, V. - ŠAMALÍKOVÁ, M. - ZEMAN, O. 1986. Geológia [Geology]. Bratislava - Praha : ALFA - SNTL, 1986. $563 \mathrm{pp}$.

TISDALL, J.M. - OADES, J.M. 1982. Organic matter and water stable aggregates in soils. In Journal of Soil Science, vol. 33, 1982, no. 2, pp. 141-163. DOI: 10.1111/ j.1365-2389.1982.tb01755.x

TOBIAŠOVÁ, E. 2011a. The effect of organic matter on the structure of soils of different land use. In Soil and Tillage Research, vol. 114, 2011, pp. 183-192.

TOBIAŠOVÁ, E. 2011b. Land use influence on micro-aggregates. In Folia Oecologica, vol. 38, 2011, no. 1, pp. $126-132$.

TORNQUIST, C.G. - MIELNICZUK, J. - CERRI, C.E.P. 2009. Modeling soil organic carbon dynamics in Oxisols of Ibiruba' (Brazil) with the Century Model. In Soil and Tillage Research, vol. 105, 2009, no. 1, pp. 33-43.

VALLA, M. - KOZÁK J. - ONDRÁČEK V. 2000. Vulnerability of aggregates separated from selected anthorsols developed on reclaimed dumpsites. In Rostliná výroba, vol. 46, 2000, pp. 563-568.

VRŠČAJ, B. - POGGIO, L. - MARSAN, F.A. 2009. A method for soil environmental quality evaluation for management and planning in urban areas. In Landscape and Urban Planning, vol. 88, 2008, pp. 81-94.

WHALEN, J.K. - CHANG, C. 2002. Macroaggregate characteristics in cultivated soils after 25 annual manure applications. In Soil Science Society of America Journal, vol. 66, 2002, no. 5, pp. 1637-1647. DOI:10.2136/ sssaj2002.1637

ZEYTIN, S. - BARAN, A. 2003. Influences of composted hazelnut husk on some physical properties of soils. In Bioresource Technology, vol. 88, 2003, pp. 241244.

Received: September 11 th 2012 